\title{
MODEL PENGELOLAAN KELAS INKLUSI DALAM PEMBELAJARAN PENDIDIKAN AGAMA ISLAM
}

\author{
Rahmah Nurfitriani \\ Dosen Prodi Pendidikan Guru Madrasah Ibtidaiyah STAIN Gajah Putih Takengon \\ E-mail: rahmahnurfitriani30@gmail.com
}

\begin{abstract}
Abstrak
Kelas inklusif merupakan kelas yang berhasil melayani peserta didik dengan karakteristik beragam, anak normal dan anak berkebutuhan khusus. Penelitian ini bertujuan untuk menganalisis karakteristik siswa berkebutuhan khusus yang bersekolah di SDN Sumbersari 1 Malang dan SDN Junrejo 01 Batu, serta menganalisis karakteristik siswa berkebutuhan khusus yang bersekolah di SDN Sumbersari 1 Malang dan SDN Junrejo 01 Batu. Strategi Pengelolaan Kelas Inklusi dan Implikasi Model Pengelolaan Kelas Inklusi Terhadap Keberhasilan Pembelajaran Pendidikan Agama Islam di Kelas Inklusi SDN Sumbersari 1 Malang dan SDN Junrejo 01 Batu.Penelitian ini menggunakan pendekatan kualitatif dengan tipe studi kasus dengan desain multisite. Hasil penelitian menunjukkan bahwa: 1) Karakteristik siswa kelas inklusi di SDN adalah: a) Siswa yang normal dan b) Siswa penyandang cacat, terdiri dari autisme, keterbelakangan mental, ADHD, tunagrahita, disleksia, gangguan emosional dan slow learner. 2) Berdasarkan karakteristik siswa, model pengelolaan kelas inklusif yang diterapkan di SDN II adalah model kelas reguler dan kelas khusus full model. Namun untuk model kelas reguler SDN Sumbersari 1 Malang menggunakan pull put. Strategi GPAI mengelola kelas reguler adalah metode pengajaran langsung secara klasikal dan pemberian tugas adalah pembedaan sesuai dengan kemampuan siswa. Sedangkan strategi pengelolaan kelas khusus penuh dilakukan oleh GPK dengan penyampaian materi dan tugas administrasi yang khusus untuk ABK. Selain pemberian GPK dari sekolah, orang tua juga berperan dalam pemberian bayangan (pendamping) bagi siswa ABK di sekolah agar pembelajaran efektif, dan 3) Implikasi model pengelolaan kelas inklusif berdampak positif terhadap hasil belajar, selain itu siswa juga dibiasakan untuk menerapkan nilai-nilai agama islam dalam kehidupan nyata, mampu beradaptasi, berkomunikasi dan bersosialisasi dengan baik satu sama lain.
\end{abstract}

Kata Kunci: Model, Pengelolaan Kelas Inklusif, Pembelajaran Pendidikan Agama Islam 


\begin{abstract}
Inclusive class is a class that managed to serve learners with diverse characteristics, normal children and children with disabilities. This study aims to analyze the characteristics of students with special needs who study in SDN Sumbersari 1 Malang and SDN Junrejo 01 Batu, and to analyze the strategy of inclusive class management and the implication of inclusive classroom management modelon the success of Islamic Education Learning in the inclusive classroom SDN Sumbersari 1 Malang and SDN Junrejo 01 Batu.This study used a qualitative approach case study type with multi-site design. The findings showed that: 1) Characteristics graders inclusion in the SDN are: a) Students who are normal and b) Students with disabilities, consists of autism, mental retardation, ADHD, physical impairment, dyslexia, emotional disturbances and slow learner. 2) Based on the characteristics students, the inclusive classroom management model applied in the second SDN is a model of regular classes and special classes full models. But for SDN Sumbersari 1 Malang regular class models using pull put. The strategies GPAI manage regular classroom is the method of direct instruction in the classical and the provision of duty is differentiation according to the students' abilities. While the full special classroom management strategies conducted by GPK with the delivery of content and administration tasks that are specific to ABK. In addition to providing GPK from school, parents also play a role in the provision of shadow (companion) for students ABK in schools so that learning is effective, and 3) Implications of the inclusive classroom management model have a positive impact on learning outcomes, in addition students are also accustomed to apply Islamic religion values in real life, able to adapt, communicate and socialize well to each other.
\end{abstract}

Keywords: Model, Inclusive Classroom Management, Islamic Education Learning 


\section{PENDAHULUAN}

Pendidikan merupakan usaha sadar dan terencana dalam mendidik generasi bangsa untuk menjadi pribadi yang mandiri dan mampu menjalankan perintah Allah sebagai hamba yang bertakwa sesuai dengan tujuan diciptakannya. Melalui pendidikan, seorang pendidik diharapkan dapat melatih, membimbing, dan mendidik generasi bangsa untuk menjadi pribadi yang berguna bagi dirinya dan bangsa.

Dalam meningkatkan kualitas pendidikan, pemerintah berupaya membuka kesempatan bagi seluruh anak Indonesia untuk mengenyam pendidikan. Salah satunya adalah membuka kesempatan bagi siswa yang memiliki kelainan fisik maupun kelemahan mental untuk tetap diterima belajar di sekolah-sekolah reguler sehingga bisa belajar bersama dengan siswa normal lain yang seusianya. Adapun program pendidikan yang digalakkan oleh pemerintah tersebut adalah program pendidikan inklusi.

Mohammad Takdir Ilahi menjelaskan bahwa pendidikan inklusi merupakan sistem layanan pendidikan yang mensyaratkan agar semua anak berkelainan dilayani di sekolahsekolah terdekat, di kelas reguler bersama teman seusianya. Melalui pendidikan inklusi, anak berkelainan dididik bersama anak lainnya (normal) untuk mengoptimalkan potensi yang dimilikinya (Mohammad Takdir Ilahi, 2013:27).

Landasan pendidikan inklusi di Indonesia diatur dalam Peraturan Menteri Pendidikan Nasional Republik Indonesia No. 70 tahun 2009 pasal 3 ayat 1 yang berbunyi "Setiap peserta didik yang memiliki kelainan fisik, emosional, mental, dan sosial atau memiliki potensi kecerdasan dan/atau bakat istimewa berhak mengikuti pendidikan secara inklusif pada satuan pendidikan tertentu sesuai dengan kebutuhan dan kemampuannya".

Menurut Mudjito dkk yang dikutib dari data Kementerian Sosial RI tahun 2008 dinyatakan bahwa:

"Total jumlah anak berkebutuhan khusus (ABK) sebanyak 1.544.184 anak. Kemudian diprediksi pada tahun 2010 angka anak berkebutuhan khusus dari umur 5-18 tahun adalah 21,42\% dari jumlah ABK dengan berbagai kekurangan/kecacatan yakni 330.764 anak. Anak berkebutuhan khusus yang sudah mendapatkan layanan pendidikan di sekolah khusus (SLB dan atau inklusi) dari jenjang Taman Kanak-kanak hingga Sekolah Menengah Pertama hanya 85.737 anak (sekitar 25,92\%). Berarti masih ada 245.027 anak $(74,08 \%)$ berkebutuhan khusus yang belum mendapat layanan pendidikan dengan berbagai jenis kelainan, dan sebagian besar mereka tinggal di perdesaan dan pusat-pusat perkotaan. Dengan demikian pendidikan inklusi masih banyak memerlukan perhatian yang sangat besar dari pemerintah sebagai penyelenggara negara yang bertanggungjawab terhadap pendidikan seperti dimanatkan dalam Undang Undang Dasar 1945 pasal 31, yakni: Ayat (1): "Setiap warga Negara berhak mendapatkan pendidikan". Ayat (2): "Setiap warga Negara wajib mengikuti pendidikan dasar dan pemerintah wajib membiayainya."( Mudjito dkk, 2012:12).

Pada saat ini pelaksanaan program pendidikan inklusi baru terlaksana di beberapa kota diantaranya adalah Jakarta, Bandung, Surabaya, Malang, Yogyakarta, dan Surakarta. Hal ini sangatlah miris karena di daerah lainnya belum terselenggara secara resmi program pendidikan inklusi di sekolah reguler, salah satunya adalah di daerah Sumetera Utara. Hal ini tidak dapat dipungkiri hadirnya anak-anak ABK di berbagai daerah, baik di daerah pusat maupun di daerah terpencil.

Banyaknya siswa ABK yang ada di Indonesia mengharuskan para praktisi pendidikan agar lebih perhatian terhadap kualitas pendidikan dalam hal pelayanan pendidikan di sekolahsekolah reguler. Sebagai praktisi pendidikan, tidak sepatutnya menolak apabila ada anak berkebutuhan khusus yang ingin mengenyam pendidikan di sekolah reguler. 
Penelitian yang telah penulis lakukan ini diharapkan dapat bermanfaat dan memberi sumbangsih untuk setiap guru di Indonesia agar mengenal model pengelolaan kelas inklusi dalam pembelajaran Pendidikan Agama Islam. Hal ini karena penelitian ini dilakukan di sekolah inklusi terbaik di Kota Malang dan di Kota Batu yang mana kedua sekolah ini adalah sekolah contoh pelaksanaan pendidikan inklusi bagi sekolah-sekolah lainnya di Jawa Timur. Oleh karena itu, guru dan calon guru di Indonesia, bukan hanya guru lulusan Pendidikan Luar Biasa saja, akan tetapi seluruh guru di Indonesia diharapkan memahami model pengelolaan kelas inklusi dan mengajarkan materi pembelajaran sesuai dengan kemampuan siswa.

\section{KAJIAN TEORETIS}

\section{Pendidikan Inklusi}

Menurut Mohammad Takdir Ilahi, pendidikan inklusif merupakan konsep pendidikan yang mempresentasikan keseluruhan aspek yang berkaitan dengan keterbukaan dalam menerima anak berkebutuhan khusus untuk memperoleh hak dasar mereka sebagai warga negara. O'Neil dalam kutipan (Mohammad Takdir Ilahi, 2014:27) juga menjelaskan bahwa pendidikan inluksi adalah sebagai sistem layanan pendidikan yang mensyaratkan agar semua anak berkelainan dilayani di sekolah-sekolah terdekat, di kelas reguler bersama teman-teman seusianya. Melalui pendidikan inklusi, anak berkelainan dididik bersama anak-anak lainnya untuk mengoptimalkan potensi yang dimilikinya.

Selaras dengan pernyataan dua pakar di atas, Sapon-Shevin dalam kutipan (Geniofam,2010:62) juga menjelaskan defenisi pendidikan inklusi, yaitu sistem layanan pendidikan yang mensyaratkan anak berkebutuhan khusus belajar di sekolah-sekolah terdekat di kelas biasa bersama teman-teman seusianya.

Berdasarkan pengertian di atas, dapat dipahami bahwa pendidikan inklusi merupakan suatu pendekatan yang inovatif dalam dunia pendidikan karena pendidikan inklusi berupaya untuk lebih memperhatikan anak-anak berkebutuhan khusus, termasuk anak penyandang cacat sehingga tidak termarginalkan dari kalangan siswa yang normal. Melalui pendidikan inklusi anak-anak yang kurang normal dapat belajar bersama dengan siswa sebayanya, tanpa memandang latar belakang fisik ataupun kekurangsempurnaan di antara mereka.

Pendidikan inklusi diharapkan dapat menjadi tempat para siswa berkebutuhan untuk dapat memperoleh ilmu pengetahuan yang sama dengan siswa normal lainnya. Meskipun tidak sesempurna pemahaman siswa normal, mereka diharapkan mampu untuk mengetahui pengetahuan dasar yang bisa menjadi bekal untuk mereka berinteraksi dengan masyarakat dan bertahan menjalani kehidupannya.

Sekolah yang menyelenggarakan pendidikan inklusi harus mampu untuk mengelola pendidikan dan proses pembelajaran sesuai dengan kemampuan siswa berkebutuhan yang berada di dalamnya. Sebagaimana pernyataan Geniofam bahwa sekolah diharapkan mampu untuk menyesuaikan kurikulum, sarana dan prasarana maupun sistem pembelajaran yang diterapkan dengan kondisi peserta didik. Sekolah inklusi harus mampu untuk mendidik dan melayani siswa berkebutuhan secara optimal, mulai dari melakukan berbagai modifikasi dan atau penyesuaian, mulai dari kurikulum, sarana dan prasarana, tenaga pendidik dan kependidikan, sistem pembelajaran hingga sistem penilaian (Geniofam,2010:62).

Oleh karena itu, pendidikan inklusi membutuhkan guru-guru yang memiliki peranan ektra untuk sabar dan tulus mendidik siswanya sesuai dengan kemampuan mereka. Guru-guru yang mengabdikan diri dalam instansi pendidikan inklusi juga harus mampu untuk mengelola proses pembelajaran menarik, nyaman, dan menyenangkan sehingga siswa selalu semangat dalam belajar dan mudah memahami materi pelajaran. 


\section{Pengelolaan Kelas Inklusi}

Pupuh Fathurrohman dan M. Sobry Sutikno (2009:104) menjelaskan pengertian pengelolaan kelas, yaitu upaya mendayagunakan seluruh potensi kelas, baik sebagai komponen utama pembelajaran maupun komponen pendukungnya. Syaiful Bahri Djamarah dan Aswan Zain juga mendefinisikan bahwa pengelolaan kelas adalah keterampilan guru untuk menciptakan dan memelihara kondisi belajar yang optimal dan mengembalikannya bila terjadi gangguan dalam proses belajar mangajar.

Berdasarkan beberapa pengertian di atas, dapat disimpulkan bahwa pengelolaan kelas adalah upaya ataupun usaha yang sengaja dilakukan oleh seorang guru dalam menciptakan suasana kelas yang kondusif agar proses pembelajaran dapat berjalan efektif dan efisien demi mencapai tujuan pembelajaran.

Menurut Geniofam (2010:64-65), model pengelolaan kelas di sekolah inklusi dapat dilakukan dengan beberapa model, diantaranya adalah sebagai berikut:

1. Kelas Reguler

Pada model ini, ABK belajar bersama anak lain (normal) sepanjang hari di kelas reguler dengan menggunakan kurikulum yang sama.

2. Kelas Reguler dengan Cluster

Dalam model ini, anak berkelainan belajar bersama dengan anak lain di kelas reguler dalam kelompok khusus.

3. Kelas Reguler dengan Pull Out

Anak berkelainan belajar dengan anak lain di kelas reguler, namun dalam waktu-waktu tertentu mereka ditarik dari kelas tersebut ke ruang sumber untuk belajar bersama dengan guru pembimbing khusus.

4. Kelas Reguler dengan Cluster dan Pull Out

Dalam model ini, ABK belajar bersama anak lain di kelas reguler dalam kelompok khusus. Dalam waktu-waktu tertentu, mereka ditarik dari kelas reguler ke ruang sumber untuk belajar dengan guru pembimbing khusus.

5. Kelas Khusus dengan Berbagai Pengintegrasian

ABK belajar di dalam kelas khusus pada sekolah reguler, namun dalam bidang-bidang tertentu dapat belajar bersama anak lain (normal) di kelas reguler.

6. Kelas Khusus Penuh

Pada model ini, anak berkelainan belajar di dalam kelas khusus pada sekolah reguler.

Dari beberapa model kelas di sekolah inklusi, dapat disimpulkan bahwa anak berkebutuhan khusus tidak selalu belajar bersama di kelas reguler bersama dengan temantemannya yang normal, sebagian dari anak berkebutuhan ada yang perlu diberikan bimbingan dan terapi di kelas khusus bersama dengan Guru Pendamping Khusus (GPK) sesuai dengan jenis kebutuhannya. Namun, jika ABK tersebut memang memiliki tingkat kelainan yang sangat besar dan tidak mungkin bisa dididik di sekolah inklusi, maka lebih dianjurkan untuk mendapatkan pendidikan di Sekolah Luar Biasa (SLB) (Geniofam,2010:65)

Pemahaman tentang model-model pengelolaan kelas inklusi haruslah benar-benar dipahami oleh seorang pendidik, karena hal ini akan sangat berpengaruh terhadap efektivitas proses pembelajaran. Oleh karena itu, sekolah inklusi berupaya untuk menganalisis kategori siswa dengan tingkat kelainannya sehingga guru dapat memberikan penanganan yang tepat untuk anak berkebutuhan di kelas inklusi tersebut.

\section{Strategi Pengelolaan Kelas}

Menurut Wina Sanjaya (2007:126), strategi diartikan sebagai perencanaan yang berisi tentang rangkaian kegiatan yang didesain untuk mencapai tujuan pendidikan tertentu. 
Sedangkan untuk mengimplementasikan rencana yang sudah disusun dalam kegiatan nyata agar tujuan yang telah disusun tercapai secara optimal dinamakan dengan metode. Strategi menunjuk pada sebuah perencanaan untuk mencapai sesuatu, sedangkan metode adalah cara yang dapat digunakan untuk melaksanakan strategi.

Berdasarkan penjabaran di atas, dapat dipahami bahwa strategi adalah suatu upaya ataupun cara yang dilakukan oleh seorang guru untuk dapat melaksanakan kegiatan pembelajaran agar dapat berjalan dengan lancar guna mencapai tujuan yang diinginkan secara efektif dan efisien. Menurut Donald P. Kachak, yang dikutip oleh Rosyada, menyarankan seorang guru harus dapat melaksanakan strategi pengelolaan kelas yang tepat diantaranya adalah sebaagai berikut:

1. Menciptakan ruang kelas yang multidimensional dan juga buatkan rancangan proses pembelajaran yang menggambarkan keragaman kemampuan belajar tersebut. Kelas multidimensional bukan berkonotasi fisik, tetapi rancangan pembelajarannya. Program pembelajaran yang sama, dilaksanakan pada kelompok yang berbeda sesuai dengan indeks kemampuan belajar mereka. Penugasan-penugasan dirancang bersifat graduatif sehingga baik kelompok yang berkemampuan tinggi maupun yang rendah tidak dirugikan. Pada akhir pelajaran, setiap kelompok menyampaikan hasil pelaksanaan tugasnya dalam sebuah kelompok besar yang konvergen yang merupakan penggabungan dari berbagai kelompok.

2. Membuat rancangan waktu yang fleksibel, tetapi tetap dalam koridor satuan waktu yang ditetapkan kurikulum. Jika satu jam pelajaran 35 menit misalnya, rancanglah bahwa anak-anak yang berkemampuan tinggi dapat menyelesaikannya dalam waktu yang lebih cepat, sementara siswa dengan berkemampuan rendah tetap dapat menyelesaikan tugas-tugasnya. Dalam hal ini dapat diberikan pengayaan kepada siswa yang berkemampuan lebih tinggi.

3. Mengelompokkan siswa berdasarkan basis kemampuannya (achievement group).

4. Mempersiapkan strategi pembelajaran untuk kelompok yang lamban dengan strategi yang tidak saja akan mengantarkan mereka memahami tugas-tuganya. Tetapi juga akan mampu meningkatkan kemampuan belajar siswa.

5. Menggunakan tutorial sebaya (peer teaching) dan belajar bersama untuk menambah kemampuan dan pengalaman mereka masing-masing. (Suyono dan Hariyanto, 2012:236).

Jika kegiatan pembelajaran dilaksanakan dengan rancangan kegiatan yang dapat meningkatkan semangat belajar siswa, tidak monoton dalam belajar, mengarahkan siswa untuk melaksanakan tugas, dan membimbingnya dengan ikhlas, suasana pembelajaran akan kondusif dan tercapai keberhasilan dalam belajar.

\section{Pendidikan Agama Islam}

Dalam kurikulum Pendidikan Agama Islam dijelaskan bahwa Pendidikan Agama Islam adalah upaya sadar dan terencana dalam menyiapkan peserta didik untuk mengenal, memahami, menghayati, mengimani ajaran agama Islam, bertakwa, dan berakhlak mulia dalam mengamalkan agama Islam dari sumber utamanya kitab suci Al-Quran dan Hadits. Melalui kegiatan bimbingan, pembelajaran, latihan, serta penggunaan pengalaman dibarengi dengan tuntutan untuk menghormati penganut agama lain dalam hubungannya dengan kerukunan antar umat dalam masyarakat hingga terwujud kesatuan dan persatuan bangsa. (Abdul Majid dan Dian Andayani, 2004:130).

Menurut Undang-Undang No.2 tahun 1989 yang dikutip oleh Aminuddin dkk, Pendidikan Agama Islam adalah usaha untuk memperkuat iman dan ketakwaan terhadap 
Tuhan Yang Maha Esa, sesuai dengan ajaran Islam, bersikap inklusif, rasional, dan filosofis dalam rangka menghormati orang lain dalam hubungan kerukunan dan kerjasama antar umat beragama dalam masyarakat untuk mewujudkan persatuan nasional.

Zakiyah Drajat (1995:55) juga memaparkan tentang pengertian Pendidikan Agama Islam, yaitu usaha untuk membina dan mengasuh peserta didik agar senantiasa dapat memahami ajaran Islam secara menyeluruh. Kemudian menghayati tujuan hingga pada akhirnya dapat mengamalkan serta menjadikan Islam sebagai pandangan hidup.

Dari beberapa pengertian di atas, dapat dipahami bahwa Pendidikan Agama Islam merupakan kegiatan yang dilakukan oleh pendidik dalam membina dan mendidik generasi muslim untuk dapat memahami ajaran Islam secara menyeluruh sehingga memiliki iman yang kokoh, dapat melaksanakan ibadah kepada Allah swt.. sesuai dengan ajaran Islam dan menjadi manusia yang selalu bertakwa kepada-Nya.

Menurut Kurikulum PAI, tujuan Pendidikan Agama Islam di sekolah/madrasah adalah untuk menumbuhkan dan meningkatkan keimanan melalaui pemberian dan pemupukan pengetahuan, penghayatan, serta pengalaman peserta didik tentang agama Islam sehingga menjadi manusia muslim yang terus berkembang dalam hal keimanan, ketakwaannya, berbangsa, dan bernegara serta untuk dapat melanjutkan pada jenjang pendidikan yang lebih tinggi ( Abdul Majid dan Dian Andayani, 2004:135)

Pendidikan Agama Islam memiliki tujuan yang sangat penting dalam kehidupan manusia di masa depan, sebagaimana tujuan pendidikan yang berorientasi pada ketakwaan terhadap Tuhan Yang Maha Esa. Sama halnya dengan tujuan pendidikan yang dipaparkan oleh Imam Al Ghazali, yaitu: Pertama, tercapainya kesempurnaan insani yang bermuara pada pendekatan diri kepada Allah. Kedua, Kesempurnaan insani yang bermuara pada kebahagiaan dunia dan akhirat (Abu Muhammad Iqbal, 2013:16)

Konsep tentang pembelajaran agama juga dicontohkan Allah dalam Al-Quran ketika Allah mengajarkan suatu ilmu yang belum diketahui oleh Rasul. Sebagaimana ayat berikut ini:

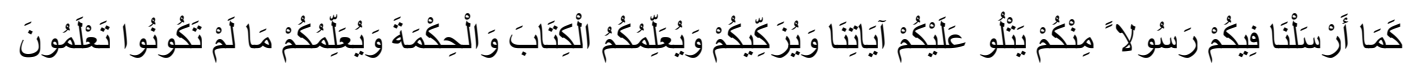

"Sebagaimana (Kami telah menyempurnakan nikmat Kami kepadamu), Kami telah mengutus kepadamu Rasul diantara kamu yang membacakan ayat-ayat Kami kepada kamu dan mensucikan kamu dan mengajarkan kepadamu al-Kitab dan hikmah, serta mengajarkan kepada kamu apa yang belum kamu ketahui."( QS. Al-Baqarah [2]: 51)

Berdasarkan dalil di atas, maka dapat dipahami bahwa Allah memberikan contoh suatu pendidikan kepada manusia untuk menyampaikan dan mengajarakan ilmu kepada orang lain dengan tujuan agar peserta didik dapat memahami ilmu yang belum diketahui, khususnya ilmu agama yang memiliki kedudukan yang sangat penting dalam pembentukan generasi muslim yang mengenal Allah dan takwa kepada-Nya.

\section{Hasil Belajar}

Setiap manusia yang telah belajar pasti mendapatkan suatu hasil yang dinamakan hasil belajar. Suatu hasil belajar dapat dilihat dari bagaimana seseorang itu telah mampu dalam memahami, merasakan dan melakukan sesuatu yang awalnya tidak bisa menjadi bisa, ataupun yang awalnya masih bersifat buruk menjadi lebih baik, dan bahkan dari seseorang yang belum dewasa menjadi dewasa. Sebagaimana menurut Robert M. Gagne (1977: 289) menyatakan bahwa hasil belajar dapat dihubungkan dengan terjadinya suatu perubahan perilaku seseorang dalam kecenderungan dengan kecakapan keterampilan pada proses pertumbuhan setelah identik dengan hasil belajar siswa.

Hasil belajar merupakan suatu bentuk penilaian terhadap hasil belajar siswa, baik itu berupa pengukuran tingkat pemahaman (pengetahuan) tentang suatu konsep atau materi, 
penilaian terhadap sikap dan tingkah laku yang berubah dari proses belajar. Seseorang yang telah belajar akan mengetahui sesuatu yang belum diketahuinya dengan ilmu. Ketika seseorang telah mampu mengerjakan sesuatu yang awalnya belum dapat dilakukannya, ia akan dikatakan telah berhasil dalam belajar karena telah dididik oleh gurunya dan juga dilandasi atas bimbingan Allah swt. Sebagaimana firman Allah dalam QS.Al-'Alaq ayat 1-5 berikut:

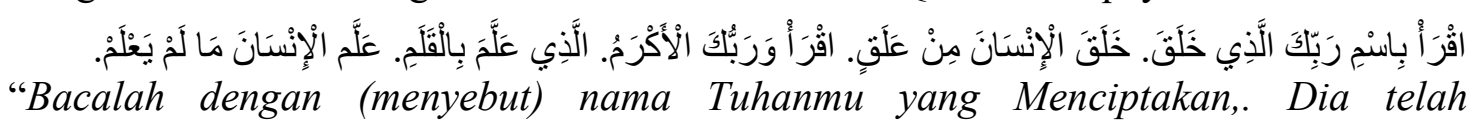
menciptakan manusia dari segumpal darah. Bacalah, dan Tuhanmulah yang Maha pemurah, Yang mengajar (manusia) dengan perantaran kalam. Dia mengajar kepada manusia apa yang tidak diketahuinya. (QS. al - 'Alaq [96]: 1-5)

Menurut Abu Ahmadi dan Supriono (2006:130) keberhasilan seseorang dipengaruhi oleh beberapa faktor. Faktor-faktor yang mempengaruhi belajar seseorang dikelompokkan menjadi dua bagian, yaitu: 1) faktor yang berasal dari dalam diri orang yang belajar (faktor internal) yang meliputi: kesehatan, intelegensi, minat dan motivasi, dan 2) faktor yang berasal dari luar diri orang yang belajar tersebut (faktor eksternal) meliputi: lingkungan keluarga, lingkungan sekolah, dan lingkungan masyarakat.

Berdasarkan penjelasan di atas, dapat ditarik benang merah bahwa kunci keberhasilan seseorang dalam belajar adalah faktor interen dari diri pelajar itu sendiri dan faktor eksteren yang mencakup orang-orang yang ada di sekitarnya. Jika di dalam diri siswa sudah terpacu semangat belajar yang tinggi, tugas pendidik atau seorang gurulah yang harus ditingkatkan untuk mampu mendidik siswa sesuai dengan caranya beajar. Cara yang dapat ditempuh adalah dengan pengelolaan kelas yang baik sebagaimana kondsi siswa agar materi pelajaran dapat dipahami oleh siswa dan hasil belajar dapat tercapai secara optimal.

\section{METODE PENELITIAN}

Pendekatan yang digunakan dalam penelitian ini adalah pendekatan kualitatif. Sebagaimana menurut Sugiono (2013:25) bahwa penelitian kualitatif dilaksanakan dengan melakukan eksplorasi secara mendalam terhadap program, kejadian, proses, aktivitas terhadap satu atau lebih orang. Suatu kasus terikat oleh waktu dan aktivitas. Peneliti melakukan pengumpulan data secara mendetail dengan menggunakan berbagai prosedur pengumpulan data dalam waktu yang berkesinambungan.

Oleh karena itu, peneliti telah melakukan penelitian ini dan mendeskripsikan secara jelas dan rinci serta mendapatkan data yang mendalam dari fokus penelitian tentang pengelolaan kelas pada mata pembelajaran Pendidikan Agama Islam di kelas inklusi SDN Sumbersari 1 Malang dan SD Negeri Junrejo 01 Kota Batu pada bulan Februari sampai Mei 2016.

Adapun jenis penelitian ini adalah studi multisitus. Penelitian kualitatif jenis multisitus ini diharapkan dapat mengembangkan banyak teori di dua jenis sekolah yang berkarakteristik sama yaitu sekolah dasar umum berbasis negeri. Selain itu, kedua sekolah ini memiliki kedudukan yang sama yaitu sebagai sekolah inti atau sering disebut dengan SD Percontohan Pendidikan Inklusi di kota Malang (SDN Sumbersari 1) dan di Kota Batu (SDN Junrejo 01).

Teknik pengumpulan data melalui pengamatan, wawancara mendalam dan dokumentasi. Teknik analisis data yang digunakan adalah dengan model Miles dan Huberman yaitu dengan reduksi data, penyajian data, dan kesimpulan. Untuk menguji keabsahan data, peneliti menggunakan uji kredibilitas dengan triangulasi data. 


\section{HASIL DAN PEMBAHASAN}

Hasil penelitian ini adalah sebagai berikut.

1. Karakteristik Siswa di Kelas Inklusi SDN Sumbersari 1 Malang dan SDN Junrejo 01 Batu

Berdasarkan penelitian yang telah dilakukan, karakteristik perkembangan siswa ABK yang pada tahun ajaran 2015/2016 di SDN Sumbersari 1 Malang dan SDN Junrejo 01 Batu terdiri atas siswa normal dan siswa ABK jenis autis, slow learner, tunadaksa, gangguan emosi, tunagrahita, ADHD (Attention Deficit Hiperactivity Disorder), dan disleksia.

Karakteristik siswa normal yaitu sehat fisik dan psikisnya dan tidak mempunyai gangguan atau kelemahan dalam memahami instruksi, pembelajaran dan mengerjakan tugas. Sedangka ABK adalah anak yang memiliki kelainan dan atau kekurangan fisik ataupun mental sehingga mengganggu proses pembelajaran. Adapun jenis dan karakteristik siswa ABK di kedua SDN tersebut adalah: 1) Anak autis memiliki karakteristik yang sulit memahami orang lain, sering melakukan hal yang berulang dan sulit berinteraksi dengan sesama, 2) Anak tunagrahita memiliki karakteristik kelambanan dalam memahami pembelajaran berbasis teori, 3) Anak ADHD yaitu sulit untuk duduk tenang dan juga mudah lupa pada pelajarannnya dan tugas-tugasnya, 4) Karakteristik siswa dengan gangguan emosional adalah anak yang selalu membuat kerusakan secara tiba-tiba dan biasanya terjadi pada anak yang pendiam, sebagaimana menurut menurut Aulia Fadhli (2010:40) adalah sering menuntut perhatian dan menunjukkan perilaku merusak jika diminta menunggu, tidak bisa berbagi dengan yang lain dan tidak memiliki kesadaran akan kebutuhan orang lain, kesulitan bermain bersama yang lain, tidak bisa menyelesaikan tugas tanpa dukungan dari orang lain, kesulitan mengikuti instruksi yang diberikan dan sulit berkonsentrasi., 5) Karakteristik anak disleksia adalah anak yang memiliki kesulitan memahami huruf dan angka sehingga sulit membaca dan kurang fokus dalam belajar, 6) Anak slow learner memiliki kelemahan dalam belajar karena malas dan rendahnya IQ dan 7)Anak tunadaksa memiliki kelemahan fisik yaitu sulit berbicara dan berjalan sehingga harus dibantu oleh guru dan orang tuanya.

2. Berdasarkan karakteristik siswa di kelas inklusi, maka pengelolaan kelas inklusi adalah dengan menggunakan model kelas reguler, model kelas khusus penuh dan model kelas reguler dengan pull out (penarikan ke kelas khusus). Adapun strategi pengelolaan kelas inklusi adalah sebagai berikut:

a. Penyusunan RPP Pendidikan Agama Islam bersifat reguler, namun untuk pelaksanaannya akan dikembangkan dan dimodifikasi sesuai dengan karakteristik siswa.

b. Pengelolaan fisik di kelas reguler menggunakan susunan bangku yaitu model $U$, teater dan kelompok acak dan penyusunan bangku di kelas khusus dengan model bangku dan meja bundar seperti konferensi atau diskusi.

c. Pembelajaran dimulai dengan doa dan bacaan surat pendek untuk menstimulus semangat siswa dan kesiapan dalam memulai pembelajaran.

d. Sebelum belajar, guru mengajak siswa untuk mereview ulang pelajaran yang telah lalu sebelum melanjut pada pembelajaran berikutnya.

e. Dalam pembelajaran di kelas reguler, guru PAI menerangkan materi secara klasikal dengan metode ceramah, eksplorasi, dan tanya jawab serta demonstrasi, namun untuk penugasan bersifat graduatif.

f. Pelaksanaan pembelajaran di kelas khusus, GPK menjelaskan materi lebih santai dan bersifat sharing sehingga pembelajaran menyenangkan dan tidak membuat siswa ABK jenuh, soal latihan pun diberikan sesuai dengan kemampuan mereka.

Pemberian materi pelajaran sesuai dengan kemampuan siswa sesuai dengan strategi pembelajaran dalam teori pendidikan Islam yang dituturkan oleh Muhammad Jawwad Ridla (2002:129), yaitu guru hendaknya menyampaikan materi pelajaran 
sesuai dengan tingkat pemahaman peserta didiknya dan terhadap peserta didik yang berkemampuan rendah, guru menyampaikan materi yang jelas, konkrit dan sesuai dengan tingkat kemampuan peserta didik dalam mencernanya.

g. Penanganan masalah siswa untuk siswa ABK adalah dengan isyarat non verbal (mengelus pundak dan kepala), menasihati dan menyemangati dengan arahan lembut, tanpa marah. Jika ada shadow, maka penanganan ABK yang bermasalah dibantu oleh shadownya.

h. Penanganan masalah siswa normal di kelas inklusi adalah dengan isyarat verbal, nonverbal dan jika perlu maka guru akan melakukan pemindahan posisi tempat duduk siswa ke kelompok siswa lainnya agar jera.

Penanganan masalah siswa di kelas sesuai dengan strategi pengelolaan masalah siswa di kelas oleh teori Carolyn T. Emmer (2011:233-239) yaitu: 1) Menggunakan isyarat non-verbal, seperti melakukan kontak mata atau isyarat gelengan kepala, jari ke bibir, menyentuh lembut siswa di lengan atau bahu siswa tanpa emosi atau marah terhadap mereka, 2) Mengawasi siswa untuk tidak melakukan perilaku yang tidak sesuai, dengan pendekatan sembari menghentikan perilaku yang tidak pantas., 3) Menggunakan peringatan kepada siswa untuk kembali fokus pada pembelajaran, kemudian mengingatkan mereka tentang perilaku yang pantas untuk dilakukan, dan 4) Mengisolasi atau memindahkan siswa ke tempat lainnya dari ruangnan tersebut jauh dari para siswa lain, apabila ia tetap mengganggu teman-temannya.

i. Pelaksanaan evaluasi pembelajaran untuk UTS dan UAS, bersifat graduatif yakni siswa ABK diberikan soal yang disederhanakan (kalimat soal disederhanakan dan dengan gambar).

3. Implikasi model pengelolaan kelas inklusi, (model kelas khusus, kelas reguler, dan model kelas reguler dengan pull out) di SDN Sumbersari 1 Malang dan SDN Junrejo 01 Batu yaitu memberikan dampak positif terhadap hasil belajara dan perkembagan kognitif, afektif dan psikomotorik siswa. Hasil belajar dilihat dari nilai siswa yang mencapai KKM. Adapun perkembangan afektif dan psikomotor siswa juga dibina melalui budaya religius yang diterapkan di lingkungan belajar, seperti shalat dhuha berjamaah, membaca surat-surat pendek sebelum masuk kelas, istighosah dan pelatihan da'i cilik setiap jumat. Kegiatan ini dapat melatih kemampuan dan perkembangan siswa untuk menjadi pribadi muslim yang bertakwa dan berakhlak mulia sesuai dengan fungsi Pendidikan Agama Islam yang dipaparkan oleh Abdul Majid (2004, 134-135),yaitu; 1) Penanaman nilai sebagai pedoman hidup untuk mencari kebahagiaan hidup di dunia dan akhirat, 2) Penyesuaian mental yaitu untuk menyesuaikan dirinya dengan lingkungan, baik fisik maupun sosial dan dapat mengubah lingkungannya sesuai dengan ajaran agama Islam, dan 3) Penyaluran, yaitu untuk menyalurkan anak-anak yang memiliki bakat khusus di bidang agar bakat tersebut dapat berkembang secara optimal sehingga dapat dimanfaatkan untuk dirinya sendiri dan bagi orang lain.

Kegiatan-kegiatan keagamaan yang dibiasakan diterapkan dalam lingkungan belajar memberikan dampak positif terhadap perkembangan afektif dan psikomotorik siswa, diantaranya siswa mampu menyampaikan dakwah singkat, mampu melaksanakan praktek sholat dengan benar dan dididik untuk terbiasa shalat dhuha, membaca ayat-ayat suci AlQuran dengan lancar dan dapat menjalin akhlakul karimah, seperti tenggang rasa, tolong menolong sesama teman, saling menghargai dan memahami keadaan teman-temannya sehingga dapat tercipta hubungan sosialisasi yang harmonis antara siswa normal dengan $\mathrm{ABK}$, sesama $\mathrm{ABK}$, dan siswa dengan guru baik di lingkungan kelas maupun lingkungan sekolah. 


\section{PENUTUP}

\section{Kesimpulan}

Adapun kesimpulan dari hasil penelitian ini adalah: 1) karakteristik siswa kelas inklusi di kedua SDN tersebut yaitu: a) Siswa normal dan b) siswa ABK, terdiri dari beberapa jenis yaitu autis, tunagrahita, ADHD, tunadaksa, disleksia, gangguan emosional dan slow learner. 2) berdasarkan karakteristik siswa, maka model pengelolaan kelas inklusi yang diterapkan di kedua SDN tersebut adalah model kelas reguler dan model kelas khusus penuh. Namun, untuk SDN Sumbersari 1 Malang model kelas reguler menggunakan pull put. Adapun strategi GPAI dalam mengelola kelas reguler adalah dengan metode pembelajaran langsung secara klasikal dan pemberian tugas bersifat diferensiasi sesuai dengan kemampuan siswa. Sedangkan strategi pengelolaan kelas khusus penuh dilakukan oleh GPK dengan penyampaian materi dan pemberian tugas yang bersifat khusus untuk ABK. Selain penyediaan GPK dari sekolah, orang tua juga berperan dalam penyediaan shadow (pendamping) bagi siswa ABK di sekolah sehingga pembelajaran berlangsung efektif,dan 3) Implikasi model pengelolaan kelas inklusi memberikan dampak positif terhadap hasil belajar, selain itu siswa juga terbiasa mengaplikasikan nilai-nilai agama Islam dalam kehidupan nyata, mampu beradaptasi, berkomunikasi dan bersosialisasi dengan baik terhadap sesama.

\section{Saran}

Berdasarkan hasil pembahasan dan kesimpulan yang telah dipaparkan, maka peneliti memberikan saran sebagai berikut:

1. Diharapkan bagi lembaga pendidikan tinggi yang ada di Indonesia memasukkan mata kuliah manajemen pendidikan inklusi untuk seluruh jurusan pendidikan, bukan hanya untuk jurusan PLB saja, sehingga dapat melahirkan para sarjana berkualitas dalam mendidik seluruh siswa, baik normal maupun ABK.

2. Diharapkan kepada pemerintah untuk lebih memberikan perhatian dalam bentuk pendanaan serta sarana dan prasarana terhadap sekolah yang menyelenggarakan program pendidikan inklusi sehingga proses pembelajaran dapat berjalan dengan baik.

3. Kepada para pendidik dan tenaga kependikan yang bertugas di lembaga pendidikan inklusi hendaknya lebih fokus untuk memperhatikan anak ABK sehingga perkembangan kognitif, afektif dan psikomotoriknya dapat tercapai lebih optimal sesuai dengan bakat dan kemampuannya.

4. Kepada Pemerintah Kota Madya Medan, khususnya Dinas Pendidikan dan Kebudayaan serta Kementrian Agama agar menyelenggarakan Program Pendidikan Inklusi secara merata di setiap daerah untuk menghindari sikap diskriminas dalam dunia pedidikan. 


\section{DAFTAR PUSTAKA}

Ahmadi, Abu dan Supriono. Psikologi Belajar, Cet. IV. Jakarta: Rineka Cipta,2006.

Djamarah, Syaiful Bahri dan Aswan Zain,Strategi Belajar Mengajar. Jakarta: PT. Rineka Cipta, 2006.

Drajat, Zakiyah. Metodik Khusus Pembelajaran Agama Islam. Jakarta: Bumi Aksara, 1995.

Evertson, Carolyn M. dan Edmund T. Emmer, Manajemen Kelas untuk Guru Sekolah Dasar, Edisi Kedelapan, Jakarta: Kencana Prenada Media Group, 2011.

Fadhli, Aulia. Buku Pintar Kesehatan Anak. Yogyakarta: Galangpress, 2010.

Fathurrohman, Pupuh dan Sobby Sutikno. Strategi Belajar Mengajar Melalui Penanaman Konsep Umum dan Konsep Islami. Bandung, Refika Aditama, 2009.

Gagne, Robert. The Condition of Learning. New York: Hart Rineheart and Winston, 1977.

Geniofam. Mengasuh dan Mensukseskan Anak Berkebutuhan Khusus. Jogjakarta: Garailmu, 2010.

Ilahi, Mohammad Takdir. Pendidikan Inklusi Konsep dan Aplikasi. Jogjakarta: Ar Ruzz Media, 2013.

Iqbal, Abu Muhammad. Konsep Pemikiran Al Ghazali tentang Pendidikan. Madiun, Jaya Star Nine, 2013.

Majid, Abdul dan Dian Andayani, Pendidikan Agama Islam Berbasis Kompetensi: Konsep dan Implementasi Kurikulum 2004. Bandung: Remaja Rosdakarya, 2005.

Mudjito dkk. Pendidikan Inklusif; Tuntunan untuk Guru, Siswa dan Orang Tua anak berkebutuhan Khusus dan layanan Khusus. Jakarta: Baduose Media, 2012.

Peraturan Menteri Pendidikan Nasional Republik Indonesia No. 70 tahun 2009.

Ridla, Muhammad Jawwad . Tiga Aliran Utama Teori Pendidikan Islam Perspektif Sosiologis-Filosofis,. Yogyakarta: Tiara Wacana Yogya, 2002.

Sanjaya, Wina. Strategi Pembelajaran Berorientasi Standar Proses Pendidikan. Jakarta: Kencana, 2007.

Sugiono. Cara Mudah Menyusun Sripsi, Tesis dan Disertasi. Bandung: Alfabeta, 2013. Suyono dan Hariyanto. Belajar dan Pembelajaran. Bandung: PT Remaja Rosdakarya, 2012. 